\title{
Nectar palatability can selectively filter bird and insect visitors to coral tree flowers
}

Susan W. Nicolson, Sara Lerch-Henning, Megan Welsford, Steven D. Johnson

\author{
S. W. Nicolson and S. Lerch-Henning \\ Department of Zoology and Entomology, University of Pretoria, Private Bag X20, Hatfield 0028, \\ South Africa \\ M. Welsford and S. D. Johnson (\&) \\ School of Life Sciences, University of KwaZulu Natal, P/Bag X01, Scottsville, Pietermaritzburg 3209, \\ South Africa \\ e-mail: Johnsonsd@ukzn.ac.za
}

\begin{abstract}
Secondary compounds in nectar may play a decisive role in determining the spectrum of floral visitors on plants. Flowers of the African coral tree Erythrina caffra are visited mainly by generalist passerine nectarivores, such as weavers and bulbuls. As the nectar of this species tastes very bitter to humans, it was hypothesized that secondary compounds may repel sunbirds and honeybees which are common in the same habitats yet seldom consume the nectar. We conducted choice tests using fresh nectar and both sucrose and hexose (glucose/fructose) solutions of the same concentration as the nectar. White- bellied Sunbirds (Cinnyris talatala) were repelled by nectar of both $E$. caffra and a related species Erythrina lysistemon, but Dark-capped Bulbuls (Pycnonotus tricolor) did not discriminate between the Erythrina nectar and control sugar solution in terms of amounts consumed. Honeybees (Apis mellifera scutellata) probed exposed droplets of E. caffra nectar and a control sugar solution at the same rate, suggesting that there is no volatile deterrent, but they immediately withdrew their proboscis far more often from the droplets of Erythrina nectar than they did from the sugar solution, suggesting that they find Ery-thrina nectar distasteful. These results contribute to a growing awareness that non-sugar components of nectar can play important functional roles in plant pollination systems.
\end{abstract}




\section{Keywords}

Bird pollination $\cdot$ Bitter nectar $\cdot$ Dilute nectar $\cdot$ Erythrina $\cdot$ Generalist nectarivores

\section{Introduction}

Mutualisms between plants and animals are often exploited by cheats which receive benefits without conferring benefits to the other organism (Bronstein 2001; RodriguezGirones and Santamaria 2005; Hargreaves et al. 2009). A variety of morphological and chemical traits of plants have been interpreted as barriers to cheating organisms. Examples include morphological structures that prevent non-mutualistic ants from gaining access to domatia of some legumes (Brouat et al. 2001) and emission by Acacia flowers of volatiles that deter ants, but not bee pollinators (Willmer et al. 2009). In plant pollination systems, secondary compounds in nectar may function as taste filters which deter animals which are morphologically or behaviourally poorly suited to be effective pollinators (Adler 2000). This was suggested for a butterfly-pollinated plant, Catalpa speciosa, in which iridoid glycosides in the nectar deter nectar robbers but not legitimate pollinators (Stephenson 1982). Filtering of flower visitors by secondary compounds has been demonstrated for phenolics in the dark nectar of Aloe vryheidenis (Johnson et al. 2006) and for unknown secondary compounds in nectar of the African milkweed Pachycarpus asperifolius (Apocynaceae), which is palatable to a pompilid wasp pollinator but not to honeybees (Shuttleworth and Johnson 2009). Taste filters are especially important for protecting exposed nectar that is potentially available to a variety of visitors.

Coral trees (Erythrina: Fabaceae) have a pantropical distribution, with Old World species pollinated by either generalist or specialist passerine birds and New World species by either generalist passerines or specialist hummingbirds (Cruden and Toledo 1977; Jacot Guillarmod et al. 1979; Neill 1987; Bruneau 1997; Raju and Rao 2004). They have red or orange flowers with copious nectar. Inflorescences of the generalist passerine-pollinated species have a broad standard petal and are relatively open, oriented inwards for easy perching by the birds. In contrast, inflorescences of the specialist passerine and hummingbird-pollinated species have a narrow standard petal and a more tubular appearance, and, in the case of hummingbird-pollinated species, are 
oriented outwards with no perch available (Cruden and Toledo 1977; Neill 1987). The floral syndrome includes nectar properties: in comparison with the species pollinated by specialist nectarivores, species pollinated by generalist passerine birds have nectar with higher volumes, lower concen- trations, a lower proportion of sucrose, and higher amino acid concentrations (Baker and Baker 1982; Bruneau 1997; Johnson and Nicolson 2008). In southern Africa, observers have noted that E. caffra and E. lysistemon are visited mainly by generalist passerine nectarivores (Jacot Guillarmod et al. 1979), while other species such as the small, shrubby E. humeana and geophytic $E$. zeyheri produce upright inflorescences with narrower flowers and are visited by specialised sunbirds (Jacot Guillarmod et al. 1979). We have also noted that while honeybees frequently collect pollen from flowers of E. caffra, they ignore the relatively exposed nectar which has a bitter taste to humans. We therefore hypothesized that the scarcity of consumption of E. caffra nectar by sunbirds and honeybees reflects a taste filter mediated by secondary compounds.

Nectars of the passerine-pollinated species of Erythrina are characterised by high amino acid concentrations (Cruden and Toledo 1977; Baker and Baker 1982; Nicolson 2007), and are also likely to contain secondary compounds such as alkaloids, which are abundant in other plant parts in Erythrina (Juma and Majinda 2004). These nectar constituents may act as a filtering mechanism for deterring flower visitors that are ineffective pollinators; even without identification of secondary compounds, their effect on pollinator behaviour can be demonstrated experimentally by comparing the responses of potential pollinators to fresh nectar and to sugar solutions of the same concentration and sugar composition. The nectar of many Erythrina species is abundant enough to be offered to bird pollinators in suitable model flowers, and the responses of bees to its taste and smell can be tested in a small arena by offering a choice of droplets (Johnson et al. 2006). We therefore tested the prediction that a specialist nectarivore, the Whitebellied Sunbird Cinnyris talatala, which occurs naturally in the same habitats as $E$. caffra and E. lysistemon, would be repelled by their nectar, while the generalist Darkcapped Bulbul Pycnonotus tricolor, a common visitor to flowers of these species, would be undeterred. We also tested the palatability of E. caffra nectar to native honeybee. 


\section{Material and Methods}

Erythrina species and nectar collection

The coastal coral tree Erythrina caffra is a medium to large deciduous tree, occurring in the coastal regions of the Eastern Cape and northern KwaZulu Natal in South Africa. Flowering takes place in winter and continues to spring (i.e. July-October) (Jacot Guillarmod et al. 1979). The flowers are orange-red with short, standard petals, the lower half of which curves upwards to expose the stamens, and are borne in densely packed inflorescences (Fig. 1). The species depends on pollinator visits for seed production (SD Johnson, unpublished). The related species Erythrina lysistemon is a tree 8-10 m tall with a wider distribution. Bright scarlet flowers are produced in winter to early spring (Jacot Guillarmod et al. 1979). As in other Erythrina species, the flowers are conspicuous because the trees are generally leafless when in flower.

To quantify the assemblage of animal flower visitors, field observations of flowers of $E$. caffra were made in semi-natural vegetation on the Pietermaritzburg campus of the University of KwaZulu Natal (six trees on six separate days between 13 August 2011 and 7 September 2011) and in natural vegetation at Oribi Gorge (a single tree, 17 September 2011). Oribi gorge is within the natural range of this species (Jacot Guillarmod et al. 1979) and the cultivated trees at Pietermaritzburg are on the edge of the range.

Nectar samples were collected with care to avoid contamination with pollen or damage to floral tissue. Nectar was sampled from 4 E. caffra trees and 8 E. lysistemon trees in the Botanical Garden on the Pietermaritzburg campus of the University of KwaZulu Natal. The standing crop volume of nectar per flower was measured with $50 \mu 1$ capillary tubes. Nectar concentration was measured using a hand-held refractometer (Bellingham and Stanley, Tunbridge Wells, UK). Additional nectar of E. caffra was collected at the same location in September 2009, its concentration measured, and then frozen in $5 \mu 1$ capillary tubes for the bee behavioural experiments. For the choice experiments with birds, nectar of E. caffra and E. lysistemon was collected from flowering trees on the campus of the University of Pretoria and at various locations in Pretoria in August-October 2009 

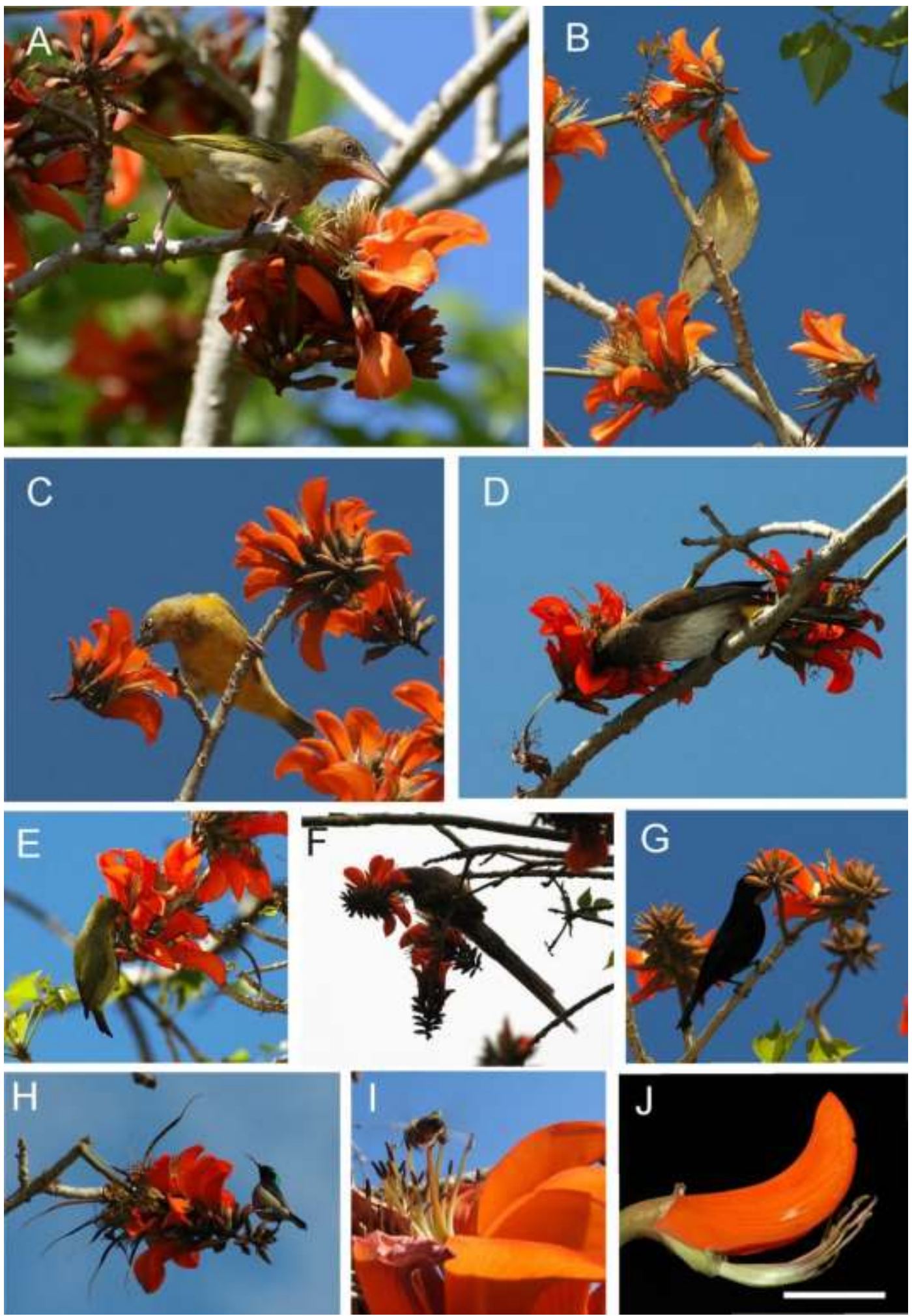

Fig. 1 Visitors to flowers of Erythrina caffra. A Female Cape weaver Ploceus capensis. B Female Cape Weaver. C Male Cape Weaver. D Dark-capped Bulbul Pycnonotus tricolor. E Cape White-eye Zosterops virens. F Speckled Mousebird Colius striatus. G Amethyst Sunbird Chalcomitra amethystina. H Southern Double-collared Sunbird Cinnyris chalybeus. I Pollen-collecting honeybee Apis mellifera scutellata. J. Single flower. Scale $=20 \mathrm{~mm}$ 
and September 2010. Nectar was collected with glass microcapillary (haematocrit) tubes, pooled in $1 \mathrm{ml}$ Eppendorf $\odot$ tubes and frozen after measurement of its concentration, which averaged $9.6 \%$ w/w for E. caffra and $17.3 \%$ for E. lysistemon.

Responses of birds to nectar of E. caffra and E. lysistemon

Six male and four female White-bellied Sunbirds (Cinnyris talatala; mean body mass $\pm \mathrm{SE}: 8.71 \pm 0.13 \mathrm{~g}$ ) were mist-netted in Jan Cilliers Park, Pretoria. Nine Darkcapped Bulbuls (Pycnonotus tricolor; $39.6 \pm 2.41 \mathrm{~g}$ ) were captured with spring-traps at the experimental farm of the University of Pretoria. Both species were housed in an outdoor aviary and fed $0.63 \mathrm{M}$ sucrose with a nutritional supplement (Ensure ${ }^{\circledR}$, Abbott Laboratories, Johannesburg, South Africa) to provide dietary nitrogen. This diet and supplementary water were provided ad libitum in inverted, stoppered syringes. In addition, bulbuls were provided daily with fresh seasonal fruits.

Choice tests were performed in the aviary with each individual tested separately in a single compartment. Birds were first deprived of food for $10 \mathrm{~min}$, then offered a choice between three test solutions: Erythrina nectar, a sucrose solution and a hexose solution (1:1 mixture of glucose and fructose), both of the same sugar concentration as the nectar. Each bird was tested twice (once with E. caffra and with E. lysistemon nectar). The test solutions were presented in three Eppendorf tubes cut in half at the $0.5 \mathrm{ml}$ mark and placed on a wooden tray in sequence. The perch position allowed birds to reach all three Eppendorf tubes easily. The test solution sequence (nectar, sucrose and hexose) and which nectar was presented first (E. caffra or lysistemon) was randomly chosen. Each Eppendorf containe $250 \mu \mathrm{l}$ of test solution and the experiment was terminated after a bird had probed all three test solutions or when one of the tubes was empty. The amount of nectar and sugar solution consumed was recorded by weighing the Eppendorf tubes before and after the trial.

Responses of honeybees to nectar of E. caffra

Native honeybees (Apis mellifera scutellata) were offered a choice between $10 \mu \mathrm{l}$ droplets of $E$. caffra nectar and $10 \mu 1$ droplets of a hexose solution (1:1 mixture of glucose and fructose) diluted to the same concentration as the nectar (10\%). Bees were 
captured while foraging in the Botanical Garden on the Pietermaritzburg campus of the University of KwaZulu Natal. They were placed in small glass vials and starved for 20-30 min prior to the start of the behavioural test. They were then transferred into inverted jars (length $10 \mathrm{~cm}$, diameter $5 \mathrm{~cm}$ ) with orange plastic lids. Droplets of $E$. caffra nectar and the sugar solution were placed $15 \mathrm{~mm}$ apart on the lid, so that bees could walk on the surface of the lid and probe the droplets. The honeybees were watched for 1 min or until each droplet was probed. The sequence in which they probed, accepted (consumed) the droplet as well as the amount of time they spent consuming the droplets was recorded. Bees were con- sidered to reject a droplet if the proboscis was immediately (one second or less) withdrawn after insertion. After the first trial, each bee was placed back in a glass vial for $5 \mathrm{~min}$ while the droplets were replenished. The same bee was then used in a second trial identical to the first one. This procedure was repeated for 25 individuals.

Statistical analysis

Behaviour data were analysed using generalized linear models implemented in SPSS 21 (IBM Corp.). To account for the repeated measures design (nectar consumption was recorded more than once for the same animal individuals) we used generalized estimating equations with animal individual treated as a subject. Models incorporated an exchange- able correlation matrix and significance was tested using Wald statistics. For analysis of the volume of solutions consumed by birds, we used models with a Gaussian distribution and identity link function. Models for the bird data included bird type and sugar solution and their interaction as predictors. For analysis of the proportion of bee choices in favour of the sugar solution in each trial and the proportion of droplets which were rejected, we used models with a binomial error distribution and logit link function. For analysis of proboscis insertion times we used models with a gamma error distribution and identity link function. Models for the bee data included trial and solution type and their interaction as predictors. For post hoc comparisons among marginal means we used the sequential Sidàk method. Data analysed using a logit link function were back-transformed for graphical presentation, resulting in asymmetrical error bars and confidence intervals. 


\section{Results}

Nectar of E. caffra and E. lysistemon

Flowers of $E$. caffra contained $134.5 \pm 25.5 \mu 1$ of nectar with a concentration of 7.7 $\pm 0.3 \%$ (mean $\pm \mathrm{SE}, \mathrm{n}=10$ ). The smaller flowers of $E$. lysistemon contained $24.8 \pm 4.7$ $\mu 1$ of nectar with a concentration of $14.4 \pm 0.3 \%(\mathrm{n}=10)$. There were significant differences in nectar volume $(\mathrm{t}=4.22, P=0.002)$ and concentration $(\mathrm{t}=14.03, P<$ 0.001 ) between the two species.

Field observations of visitors to $E$. caffra flowers

The overwhelming majority of avian visitors observed feeding from flowers of $E$. caffra were occasional (generalist) nectarivores (Fig. 1, Table 1). Weavers, of which females

Table 1 Birds foraging at flowers of Erythrina caffra

\begin{tabular}{lllrrrr}
\hline Family & Species & Common name & \multicolumn{2}{c}{ Number } \\
& & & Total $(\%)$ & Bill length (mm) \\
\hline Coliidae & Colius striatus & Speckled & 0 & 17 & 8.4 & 13.1 \\
Oriolidae & Oriolus larvatus & Black-headed & 1 & 0 & 0.5 & 30.6 \\
Pycnonotida & Pycnonotus tricolor & Dark-capped & 1 & 9 & 4.9 & 19.2 \\
Zosteropidae & Zosterops virens & Cape white-eye & 1 & 31 & 15.8 & 13.6 \\
Sturnidae & Sturnus vulgaris & Common starling & 2 & 0 & 1.0 & 29.2 \\
& Onychognathus morio & Red-winged & 2 & 0 & 1.0 & 32.8 \\
& Acridotheres tristis & Common myna & 0 & 4 & 2.0 & 27.4 \\
Nectariniida & Chalcomitra & Amethyst sunbird & 3 & 5 & 3.9 & 30.8 \\
Ploceidae & Ploceus capensis & Cape weaver & 0 & 8 & 3.9 & 23.5 \\
& Ploceus cucullatus & Village weaver & 14 & 19 & 16.3 & 19.5 \\
& & Weaver, & 80 & 6 & 42.4 & - \\
& & Total & 104 & 99 & 100 & \\
\hline
\end{tabular}

Observations were on six flowering trees on the Pietermaritzburg campus of the University of KwaZulu Natal (PMB) between 13 August and 7 September 2011, and at a single tree at Oribi Gorge (OB) on 17 September 2011. All observations were made between 0930 and 1500 hours. Bill lengths are taken from Hockey et al. (2005)

and males in non-breeding plumage could not be identified to species, made up $62.6 \%$ of all observed visitors at the two sites. White-eyes, mousebirds and bulbuls were also 
abundant visitors, while specialist sunbirds were recorded infrequently, despite being common in the surrounding habitat where they fed on flowers of other species. Honeybees, although regular visitors, were not observed to feed on nectar and exclusively collected pollen (Fig. 1I).

Responses of birds to nectar of E. caffra and E. lysistemon

Overall consumption rates were comparable between bird species and Erythrina species (Fig. 2), as expected when the volume available was $250 \mu \mathrm{l}$ of each test solution and the experiment was terminated after a bird had probed all three solutions or emptied one of the tubes. In the experiments involving E. caffra (Fig. 2A), there were significant overall effects of bird species on volume consumed $\left(\mathrm{v}^{2}=10.8, P=0.001\right)$, solution type $\left(\mathrm{v}^{2}=18.2, P<0.001\right)$ and the interaction between bird species and solution type on volume consumed $\left(\mathrm{v}^{2}=18.1, P<0.001\right)$. Dark-capped Bulbuls showed no preference among solutions, while sunbirds consumed significantly less of the E. caffra nectar than of the sugar solutions and also preferred sucrose over hexose solutions (Fig. 2A).

In the experiments involving E. lysistemon (Fig. 2B), there were significant effects of bird species $\left(\mathrm{v}^{2}=65.1, P<0.001\right)$, solution type $\left(\mathrm{v}^{2}=94.8, P<0.001\right)$ and a significant interaction between bird species and solution type on volume consumed $\left(\mathrm{v}^{2}\right.$ $=18.9, P<0.001)$. Dark-capped Bulbuls showed no preference among solutions, while sunbirds consumed significantly less of the E. lysistemon nectar than of the sugar solutions and preferred sucrose over hexose solutions (Fig. 2B). Sunbirds were seen to shake their heads in about half the tests with both nectars, but this behaviour was not observed in bulbuls.

Responses of honeybees to nectar of $E$. caffra

Honeybees did not discriminate between E. caffra nectar and the control hexose sugar solution in terms of which of these solutions was probed first in trials, as indicated by 95 $\%$ confidence limits around the mean values for the proportion of first probes to the 
A

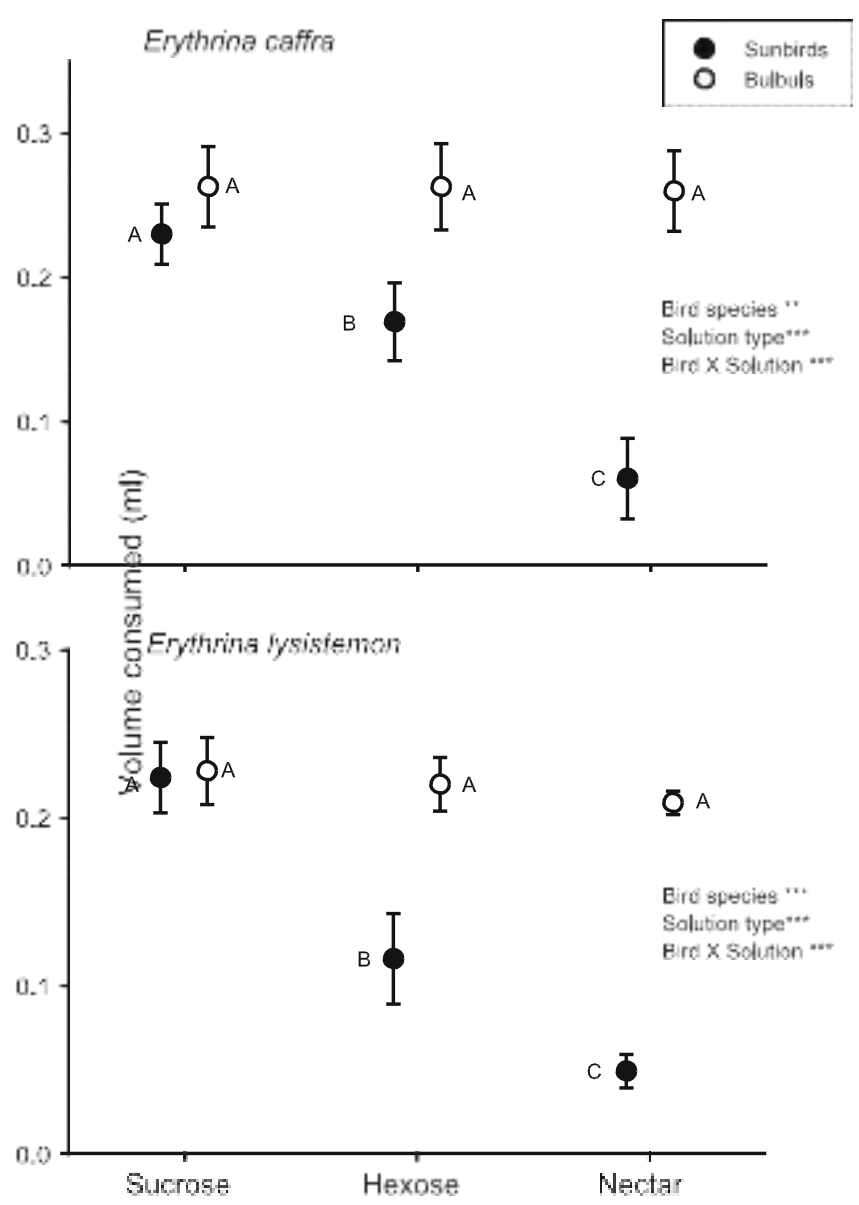

Fig. 2 Responses of sunbirds and bulbuls to nectar of Erythrina caffra (A) and Erythrina lysistemon (B). White-bellied sunbirds Cinnyris talatala $(n=10)$ and dark-capped bulbuls Pycnonotus tricolor $(n=$ 9) in an aviary were offered nectar and sugar solutions of the same concentration. Treatment means for birds of the same species that share letters do not differ significantly. Significance of predictors is indicated by asterisks: $* * P<0.01, * * * P<0.001$

sugar solution (Fig. 3). There was also no significant difference between trials in terms of which solution was probed first $\left(\mathrm{v}^{2}=1.15, P=0.28\right.$, Fig. 3$)$. 


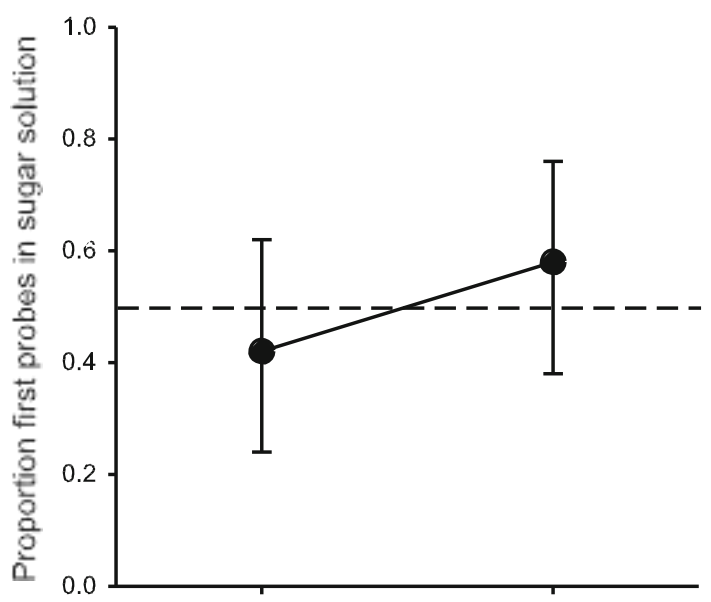

Fig. 3 Proportion of first probes in sugar solution droplets by honeybees offered a choice between Erythrina nectar and a control sugar solution in two consecutive trials. Bars indicate $95 \%$ CIs around the mean and the dotted line indicates the 0.5 value of equal choice.

The proportion of probes with immediate proboscis withdrawal was far higher for $E$. caffra nectar than for control sugar solutions $\left(\mathrm{v}^{2}=15.3, P<0.001\right.$, Fig 4A). Rejection rates increased in the second trial in which honeybees rejected Erythrina nectar in more than $90 \%$ of probes $\left(\mathrm{v}^{2}=13.1, P<0.001\right.$, Fig. 4 A), but there was no significant interaction between trial number and solution type on rejection rates $\left(\mathrm{v}^{2}=0.31, P=0.57\right.$, Fig. 4A). The overall mean amount of time that bees inserted their proboscis in the solutions was much greater for the control sugar solution than for the Erythrina nectar $\left(\mathrm{v}^{2}=17.6, P<0.001\right.$, Fig. 4B) and also decreased significantly between trials $\left(\mathrm{v}^{2}=\right.$ 17.4, $P<0.001$, Fig. 4B), with no significant interaction between trial number and solution type $\left(\mathrm{v}^{2}=0.18, P=0.66\right.$, Fig. 4B). Because the droplets spread out over the plastic surface, we were unable to record the exact volume of solution consumed, but it was noted that sugar solutions were invariably consumed, while most Erythrina droplets remained intact, particularly in the second trial when none were consumed. 

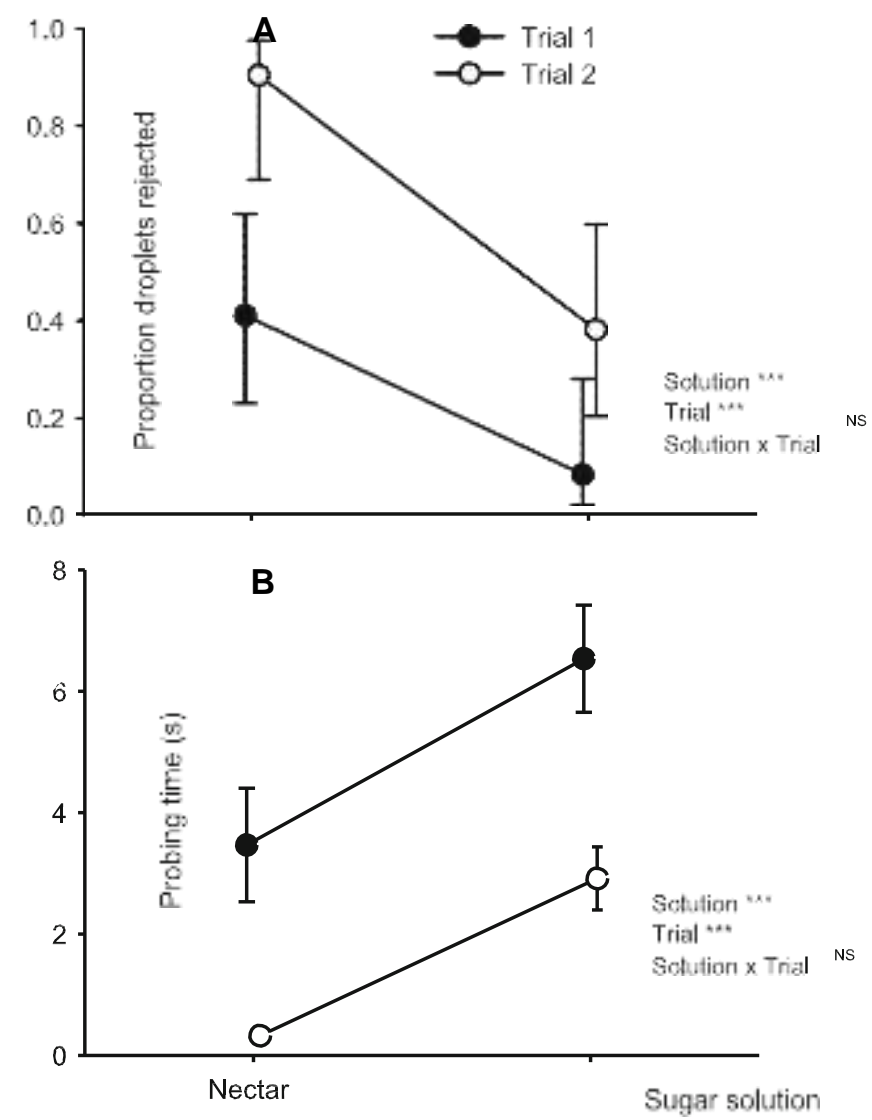

Fig. 4 Responses of honeybees to droplets of Erythrina nectar and control sugar solutions in two consecutive trials. A Proportion of droplets rejected (immediate proboscis withdrawal). B Mean time of proboscis insertion into droplets. Significance of predictors is indicated by asterisks: NS nonsignificant, $* * * P<0.001$

\section{Discussion}

Our field observations show that flowering trees of Erythrina caffra are highly attractive to generalist bird pollinators with relatively short bills, such as mousebirds, bulbuls, whiteeyes and weavers, while sunbirds are relatively minor visitors and honeybees avoid the nectar altogether and only collect pollen. We hypothesized that secondary compounds in nectar deter sunbirds and honeybees, but another possible explanation for the observed spectrum of visitors is that sunbirds and honeybees are deterred by very low sugar concentration of the nectar (c. 7-10\%) and by its composition entirely of hexose sugars. Our experiments, however, showed that nectar of the Erythrina species is avoided more often than control solutions that match the sugar-related properties of the nectar. This strongly points to secondary compounds as the basis for the deterrent effect of Erythrina nectar on sunbirds and honeybees in the laboratory experiments. 
Our experiments do not exclude the possibility that sugar-related properties of Erythrina nectar play additional roles in filtering the pollinator assemblage in the field. There is a strong global correlation between dilute hexose-dominated nectar and pollination by generalist birds (Johnson and Nicolson 2008). In laboratory experiments, Village Weavers Ploceus cucullatus offered solutions of low sugar concentrations resembling those of $E$. caffra nectar, have been found to prefer hexose solutions to equicaloric sucrose solutions and to absorb hexose sugars more efficiently than sucrose (Odendaal et al. 2010). Similar preferences have been observed in Speckled Mousebirds (Brown et al. 2010b), while Dark- capped Bulbuls show even stronger hexose preference, choosing hexose rather than sucrose solutions at any nectar concentration (Brown et al. 2010a). In the present study, however, they did not differentiate between sucrose and hexose solutions. In this study, White- bellied Sunbirds consumed more sucrose than hexose solution, whereas in a previous study Fleming et al. (2004) found that this species had no sugar preference except at extremely dilute nectars, when they chose hexose solutions. However, it may not be valid to compare a choice between two solutions in large-volume feeders with a three-way choice between solutions in small vials. Patterns of sugar preference in avian nectarivores are generally correlated with intestinal sucrose activity, i.e. their ability to hydrolyse sucrose (Napier et al 2013).

The flowers of E. caffra are well suited for pollination by short-billed generalist avian nectarivores (Fig. 1). These birds make contact with the anthers and stigma and carry visible loads of Erythrina pollen on their faces. By contrast, sunbirds often feed sideways and don't contact reproductive parts of the flowers. Honeybees, if they did feed on nectar, would not contact the reproductive parts at all. While honeybees are not usually associated with Erythrina flowers, they have been recorded foraging for nectar (and contacting stigmas) at E. sigmoidea in Cameroon (Tchuenguem Fohouo et al. 2010), and E. abyssinica is listed as a bee plant in Tanzania (Latham 2001). Erythrina crista-galli in Argentina and Uruguay is pollinated by honeybees, carpenter bees and hummingbirds (Galetto et al. 2000). However, other observations of bees on Erythrina flowers suggest they are not legitimate pollinators (Feinsinger et al. 1979; Cotton 2001; Etcheverry and Trucco Alemán 2005).

The behavioural responses of birds and bees to Erythrina nectar were very similar to those found in experiments with nectar of Aloe vryheidensis, which is dark and bitter, due to 
phenolic compounds (Johnson et al. 2006). Its consumption by Dark-capped Bulbuls did not differ from that of hexose and sucrose controls, while Amethyst Sunbirds (Chalcomitra amethystina) and honeybees strongly rejected it (Johnson et al. 2006). Head-shaking behaviour was also seen in sunbirds offered the nectar of A. vryheidensis, which seems to be even more repellent to sunbirds than the Erythrina nectars. In most previous studies of the effects of secondary compounds in nectar, broad spectrum repulsive effects have been and Baldwin 2007; Adler and Irwin 2012). Interestingly, in both Erythrina caffra and A. vryheidensis, there is no evidence of such trade-offs and it seems that the generalist birds are completely undeterred by nectar which is unpalatable to other potential flower visitors.

Honeybees did not discriminate between Erythrina nectar and the control sugar solution in terms of which solution was probed first, and this did not vary between trials (Fig. 3). This suggests that the basis of honeybee rejection of Erythrina nectar is not related to olfaction. Instead, honeybees responded to Erythrina nectar by rapidly withdrawing their proboscis. A higher proportion of Erythrina droplets were rejected (and probing time decreased) in the second trial (Fig. 4), but this also applied to the hexose solution (as reflected in the non-significant interaction between trial and solution type) and this sug-gests that the change in behaviour between trials may have resulted from satiation rather than learning.

While our experiments point to secondary compounds in E. caffra nectar as the basis of its unpalatability to sunbirds and honeybees, we have not been able to identify the cause of the bitter taste of the nectar to humans. Erythrina is well studied in terms of nectar chemistry (Baker and Baker 1982; Nicolson 2007; Johnson and Nicolson 2008). Erythrina species that are pollinated by specialist birds differ in nectar volume, sugar type and concentration, and amino acid concentration from species pollinated by generalist birds (Baker and Baker 1982; Johnson and Nicolson 2008). Erythrina species, commonly used in traditional medicine, are rich in isoquinoline alkaloids, especially in the highly toxic seeds (Romeo and Bell 1974). Alkaloids have also been identified in the flowers of $E$. lysistemon (Juma and Majinda 2004), and it is common for secondary metabolites in leaves and flowers to occur in nectar (Adler et al. 2012). Lectins, small proteins that are common seed defences, have also been characterised from Erythrina, including E. caffra and E. lys-istemon (Lis et al. 1985), and may be present in the nectar. Leek (Allium porrum) nectar contains a mannose-binding lectin (Peumans et al. 1997). Nectar of both 
E. caffra and E. lysistemon has very high amino acid concentrations, including non-protein amino acids (Nicolson 2007), and some amino acids are known to have a bitter taste (Gardener and Gillman 2002). It is clear that the bitter taste of E. caffra nectar could be derived from any of a number of compounds. Baker and Baker (1982) reported the presence of phenolics in most of the Erythrina species they tested, but not alkaloids: however, these were quali- tative tests only. Our own investigations indicate that there are no detectable phenolics in E. caffra nectar (SD Johnson, unpublished data).

The combination of low sugar and high amino acid concentrations in nectars of Erythrina species means that relatively large amounts of amino acids may be ingested. We have previously tested the responses of White-bellied Sunbirds to amino acids in $20 \%$ sucrose solutions (Leseigneur et al. 2007): some were avoided at $15 \mathrm{mM}$, including asparagine and serine, which together occur at even higher concentrations in nectar of $E$. caffra and $E$. lysistemon (Nicolson 2007). Moreover, the taste of amino acids and any secondary metabolites will be more apparent in dilute nectars. Sunbirds, white-eyes and bulbuls show reduced tolerance to the alkaloid nicotine in more dilute sucrose solutions (LerchHenning and Nicolson 2013). Bulbuls are more tolerant than sunbirds to nicotine in artificial nectar, and their sugar assimilation efficiency is unaffected by nicotine (S. LerchHenning, unpublished data).

The spectrum of generalist nectarivores visiting E. caffra flowers is comparable with that recorded for other plants with abundant dilute (12\% w/w) nectar, such as Aloe marlothii (Symes et al. 2011), Aloe ferox (Botes et al. 2008) and Aloe vryheidensis (Johnson et al. 2006). Birds may tolerate these dilute and sometimes bitter nectars for the benefit of a large and predictable nectar supply during mass flowering in the dry season, when other food resources are scarce. Occasional avian nectarivores may be more tolerant to secondary metabolites in nectar because of the occurrence of natural toxins in their seasonally varying diets.

\section{Acknowledgments}

This research was funded by the South African National Research Foundation (NRF). 
We thank the Gauteng Directorate of Nature Conservation and Jan Celliers Park for permission to capture and house the birds. All bird care procedures and experimental protocols followed the institutional regulations of the University of Pretoria (EC022-09).

\section{Reference}

Adler LS (2000) The ecological significance of toxic nectar. Oikos 91:409-420

Adler LS, Irwin RE (2012) Nectar alkaloids decrease pollination and female reproduction in a native plant. Oecologia 168:1033-1041

Adler LS, Seifert MG, Wink M, Morse GE (2012) Reliance on pollinators predicts defensive chemistry across tobacco species. Ecol Lett 15:1140-1148

Baker I, Baker HG (1982) Some chemical constituents of floral nectars of Erythrina in relation to pollinators and systematics. Allertonia 3:25-37

Botes C, Johnson SD, Cowling RA (2008) Coexistence of succulent tree aloes: partitioning of bird poll- inators by floral traits and flowering phenology. Oikos $117: 875-882$

Bronstein JL (2001) The exploitation of mutualisms. Ecol Lett 4:277-287

Brouat C, Garcia N, Andary C, McKey D (2001) Plant lock and ant key: pairwise coevolution of an exclusion filter in an ant-plant mutualism. Proc R Soc B 268:21312141

Brown M, Downs CT, Johnson SD (2010a) Sugar preferences and digestive efficiency in an opportunistic avian nectarivore, the Dark-capped Bulbul Pycnonotus tricolor. J Ornithol 151:637-643

Brown M, Downs CT, Johnson SD (2010b) Sugar preferences of a generalist nonpasserine flower visitor, the African Speckled Mousebird (Colius striatus). Auk 127:781-786

Bruneau A (1997) Evolution and homology of bird pollination syndromes in Erythrina (Leguminosae). Am J Bot 84:54-71

Cotton PA (2001) The behavior and interactions of birds visiting Erythrina fusca flowers in the Colombian Amazon. Biotropica 33:662-669 
Cruden RW, Toledo VM (1977) Oriole pollination of Erythrina breviflora (Leguminosae): evidence for a polytypic view of ornithophily. Plant Syst Evol 126:393403

Etcheverry AV, Trucco Alemán CE (2005) Reproductive biology of Erythrina falcata (Fabaceae: Papi- lionoideae). Biotropica 37:54-63

Feinsinger P, Linhart YB, Swarm LA, Wolfe JA (1979) Aspects of the pollination biology of three Erythrina species on Trinidad and Tobago. Ann Mo Bot Gard 66:451-471

Fleming PA, Hartman Bakken B, Lotz CN, Nicolson SW (2004) Concentration and temperature effects on sugar intake and preferences in a sunbird and a hummingbird. Funct Ecol 18:223-232

Galetto L, Bernardello G, Isele IC, Vesprini J, Speroni G, Berduc A (2000) Reproductive biology of Erythrina crista-galli (Fabaceae). Ann Mo Bot Gard 87:127145

Gardener MC, Gillman MP (2002) The taste of nectar-a neglected area of pollination ecology. Oikos 98:552-557

Gegear RJ, Manson J, Thomson J (2007) Ecological context influences pollinator deterrance by alkaloids in floral nectar. Ecol Lett 10:375-382

Hargreaves AL, Harder LD, Johnson SD (2009) Consumptive emasculation: the ecological and evolutionary implications of pollen theft. Biol Rev 84:259-276

Hockey PAR, Dean WRJ, Ryan PG (eds) (2005) Roberts—birds of Southern Africa, VII edn. The Trustees of the John Voelcker Bird Book Fund, Cape Town

Jacot Guillarmod A, Jubb RA, Skead CJ (1979) Field studies of six Southern African species of Erythrina. Ann Mo Bot Gard 66:521-527

Johnson SD, Nicolson SW (2008) Evolutionary associations between nectar properties and specificity in bird pollination systems. Biol Lett 4:49-52

Johnson SD, Hargreaves AL, Brown M (2006) Dark bitter-tasting nectar functions as a filter of flower visitors in a bird-pollinated plant. Ecology 87:2709-2716

Juma BF, Majinda RRT (2004) Erythrinaline alkaloids from the flowers and pods of Erythrina lysistemon and their DPPH radical scavenging properties. Phytochemistry 65:1397-1404 
Kessler D, Baldwin IT (2007) Making sense of nectar scents: the effects of nectar secondary metabolites on floral visitors of Nicotiana attenuata. Plant Journal 49:840 854

Latham P (2001) Beekeeping and some honeybee plants in Umalila. Southern Tanzania. In, Bees for Development

Lerch-Henning S, Nicolson SW (2013) Bird pollinators differ in their tolerance of a nectar alkaloid. J Avian Biol 44:408-416

Leseigneur CDC, Verburgt L, Nicolson SW (2007) Whitebellied sunbirds (Nectarinia talatala, Nectari- niidae) do not prefer artificial nectar containing amino acids. J Comp Physiol B 177:679-685

Lis H, Joubert FJ, Sharon N (1985) Isolation and properties of $n$-acetyllactosamine-specific lectins from nine Erthyrina species. Phytochemistry 24:2803-2809

Napier KR, McWhorter TJ, Nicolson SW, Fleming PA (2013) Sugar preferences of avian nectarivores are correlated with intestinal sucrase activity. Physiol Biochem Zool $86: 499-514$

Neill DA (1987) Trapliners in the trees: hummingbird pollination of Erythrina sect. Erythrina (Legumi- nosae: Papilionoideae). Ann Mo Bot Gard 74:27-41

Nicolson SW (2007) Amino acid concentrations in the nectars of southern African birdpollinated flowers, especially Aloe and Erythrina. J Chem Ecol 33:1707-1720

Odendaal TC, Brown M, Downs CT, Johnson SD (2010) Sugar preferences and digestive efficiency of the village weaver: a generalist avian pollinator of African plants. J Exp Biol 213:2531-2535

Peumans WJ, Smeets K, Van Nerum K, Van Leuven F, Van Damme EJM (1997) Lectin and alliinase are the predominant proteins in nectar from leek (Allium porrum L.) flowers. Planta 201:298-302

Raju AJS, Rao SP (2004) Passerine bird pollination and fruiting behaviour in a dry season blooming tree species, Erythrina suberosa Roxb. (Fabaceae) in the Eastern Ghats forests

India. Ornithol Sci 3:139-144

Rodriguez-Girones MA, Santamaria L (2005) Resource partitioning among flower 
visitors and evolution of nectar concealment in multi-species communities. Proc R Soc B Biol Sci 272:187-192

Romeo JT, Bell EA (1974) Distribution of amino acids and certain alkaloids in Erythrina species. Lloydia 37:543-568

Shuttleworth A, Johnson SD (2009) The importance of scent and nectar filters in a specialized wasp- pollination system. Funct Ecol 23:931-940

Stephenson AG (1982) Iridoid glycosides in the nectar of Catalpa speciosa are unpalatable to nectar thieves. J Chem Ecol 8:1025-1034

Symes CT, McKechnie AE, Nicolson SW, Woodborne SM (2011) The nutritional significance of a winter- flowering succulent for opportunistic avian nectarivores. Ibis 153:110-121

Tchuenguem Fohouo F-N, Tope SF, Mbianda AP, Messi J, Brückner D (2010) Foraging behaviour of Apis mellifera adansonii (Hymenoptera: Apidae) on Combretum nigricans, Erythrina sigmoidea, Lannea kerstingii and Vernonia amygdalina flowers at Dang (Ngaoundéré, Cameroon). Int J Trop Insect Sci 30:40-47

Willmer PG et al (2009) Floral volatiles controlling ant behaviour. Funct Ecol 23:888-900 